\title{
Diel rhythm does not shape the vertical distribution of bacterial and archaeal 16S rRNA transcript diversity in intertidal sediments: a mesocosm study
}

\author{
C. Lavergne ${ }^{1,2}$, M. Hugoni ${ }^{3}$, C. Hubas $^{4}$, D. Debroas ${ }^{5,6}$, C. Dupuy ${ }^{1}$, H. Agogué ${ }^{1}$
}

\section{Corresponding author:}

Céline Lavergne, School of Biochemical Engineering, Pontificia Universidad Católica de Valparaíso, Avenida Brasil 2085, Valparaíso, Chile

e-mail: celine.lavergne@pucv.cl; lavergne.celine@gmail.com

Running title: Diel activities of benthic Bacteria and Archaea

Conflict of interest: The authors declare no conflict of interest.

\footnotetext{
1 Université de La Rochelle - CNRS, UMR 7266, LIENSs, 2 rue Olympe de Gouges, 17000 La Rochelle, France

2 School of Biochemical Engineering, Pontificia Universidad Católica Valparaíso, Avenida Brasil 2085, Valparaíso, Chile

3 Université Lyon 1; CNRS, UMR5557; Ecologie Microbienne; INRA, UMR1418; 69220 Villeurbanne Cedex, France

4 Muséum National d'Histoire Naturelle, UMR BOREA, Sorbonne Universités, UPMC Univ Paris 6, CNRS 7208, IRD 207, UCN, UA, Station de Biologie Marine, 29900, Concarneau, France

${ }^{5}$ Clermont Université, Université Blaise Pascal, LMGE, BP 10448, 63000 Clermont-Ferrand, France

${ }^{6}$ CNRS, UMR 6023, LMGE, 63171 Aubière, France
} 


\section{Abstract}

In intertidal sediments, circadian oscillations (i.e., tidal and diel rhythms) and /or depth may affect prokaryotic activity. However, it is difficult to distinguish the effect of each single force on active community changes in these natural and complex intertidal ecosystems. Therefore, we developed a tidal mesocosm to control the tidal rhythm and test whether diel fluctuation or sediment depth influence active prokaryotes in the top $10 \mathrm{~cm}$ of sediment. Day- and nighttime emersions were compared as they are expected to display contrasting conditions through microphytobenthic activity in five different sediment layers. A multiple factor analysis revealed that bacterial and archaeal $16 \mathrm{~S}$ rRNA transcript diversity assessed by pyrosequencing was similar between day and night emersions. Potentially active benthic Bacteria were highly diverse and influenced by chlorophy1 $a$ and phosphate concentrations. While in oxic and suboxic sediments, Thaumarchaeota Marine Group I (MGI) was the most active archaeal phylum, suggesting the importance of the nitrogen cycle in muddy sediments, in anoxic sediments, the mysterious archaeal $\mathrm{C} 3$ group dominated the community. This work highlighted that active prokaryotes organise themselves vertically within sediments independently of diel fluctuations suggesting adaptation to physicochemical specific conditions associated with sediment depth.

Keywords: Archaea / Bacteria / active community / intertidal mudflat / mesocosm / diel cycle / microphytobenthic biofilm 


\section{Introduction}

Diversity, activity and abundance of bacterial and archaeal communities in coastal mudflats vary greatly in space and time because of sharp gradients in salinity, temperature, nutrient concentration, oxygen and redox potential [1-4]. Other factors, such as depth $[2,5]$ and/or diel rhythm (i.e., day/night conditions) [6], may influence microbial community composition in intertidal zones. In these areas, the vertical distribution of prokaryotic communities depends on climatic factors such as storms, precipitation [7], tide, wind or wave action [8-10] as well as variations of biotic and others abiotic determinants such as salinity and temperature [11], organic carbon availability [12-14], inorganic nutrient content [15], bioirrigation and bioturbation [16-18], and microphytobenthic activity [19,20].

The high productivity recorded in intertidal mudflats [21] is partly due to the formation of a transient microphytobenthic biofilm that can develop at the surface during daily tidal exposure periods [22-24]. Studies have shown that microphytobenthos (MPB) impacted the prokaryotic community structure and activity by producing large amounts of extracellular polymeric substances [25] but also by uptaking large quantities of nutrients during the day $[19,26]$. Few studies have inyestigated the fate of the organic matter produced and its impact on prokaryotic community composition during night-time high tide $[8,9]$. At high tide, Thornton et al. [27] observed a drastic uptake of ammonium during the day compared to the night, suggesting shifts in the microbial groups involved in the nitrogen cycle. Moreover, a modelling approach in a subtidal estuary revealed a strong decrease in nitrification and denitrification rates associated with an increase in photosynthesis during the daytime [20], consistent with competition between MPB and prokaryotic communities for nutrient uptake [19]. All of this highlighted the importance of considering the co-occurrence of microphytobenthos and prokaryotes for understanding the ecological drivers of active bacterial and archaeal community structure. Together, these studies have revealed that 
intertidal systems experience drastic changes during the tidal or/and diel cycle and highlight the complexity of microbial interactions in a spatially heterogeneous and temporally varying habitat.

By considering a simplified intertidal system (i.e., at low tide), we aimed at testing whether microphytobenthic activity, and/or depth represented by the variation in environmental conditions shape active prokaryotic assemblages over a $24 \mathrm{~h}$ period. We hypothesized that, at low tide, prokaryotic 16S rRNA transcript diversity may be different between day and night conditions as a result of an intense benthic primary production by diatoms during the day. The mix of regional and local factors that influence prokaryotic community composition in marine ecosystems and their relations are difficult to evaluate with in situ surveys [28]. Thus, we designed a tidal mesocosm experiment, with day and night exposure, to assess bacterial and archaeal 16S rRNA transcript diversity from five different depths of intertidal muddy sediments.

\section{Experimental procedures}

\subsection{Sampling and tidal mesocosm set-up}

Muddy sediment samples (mean grain size: $11.7 \mu \mathrm{m} \pm 1.63 \mu \mathrm{m}$ ) were collected in April 2013 on the ridges at low tide in the intertidal mudflat of Marennes-Oléron Bay (France, $\mathrm{N} 45^{\circ} 54^{\prime}$ 53"; W $\left.01^{\circ} 05^{\prime} 23^{\prime \prime}\right)$. Cores from 0 to $10 \mathrm{~cm}$ below sediment surface (bsf) were sliced into five layers $(0-0.5 \mathrm{~cm}, 0.5-1 \mathrm{~cm}, 1-2 \mathrm{~cm}, 2-5 \mathrm{~cm}$ and $5-10 \mathrm{~cm})$. Next, in the laboratory, each layer was sieved by hand without seawater addition through $500-\mu \mathrm{m}$-pore-sized mesh to remove macrofauna (i.e., grazers and bioturbators). The experimental PVC cores (height: $12 \mathrm{~cm}$; diameter $12.5 \mathrm{~cm}$ ) were reconstituted layer by layer and arranged in the main tank according to previous work [29], (Figure 5.a). 
The tidal mesocosms consisted of a main tank and an overflow tank (Figure 5.a). Two identical tidal mesocosms were designed to study both day and night low tides (Figure 5.b). For the daytime mesocosm (Day, Figure 5.b), the experiment was started at 4 am with a simulated high tide; $15 \mathrm{~h}$ of light was followed by a dark cycle (light/dark 15:9, corresponding to the field light/dark conditions in April 2013) with a low or high tide every $6 \mathrm{~h}$ that was simulated by gradually rising or lowering the water level. For the night-time mesocosm (Night, Figure 5.b), the experiment was started at 4 am with a simulated high tide; $15 \mathrm{~h}$ of dark was followed by a light cycle (light/dark 15:9) with a low or high tide every $6 \mathrm{~h}$. The cores were placed in the dark submitted to tidal cycle in the mesocosm for a two-week period before the experiment for nutrient equilibration. Water collected from Marennes-Oléron Bay was filtered through a $0.2-\mu \mathrm{m}$ mesh and used for the overflow and recirculation system. After the settling period of two weeks, the cores were inoculated using $500-\mu \mathrm{m}$-sieved fresh MPB biofilm (chlorophyll $a$ concentration: 118.96 and $87.19 \mu \mathrm{g} \mathrm{g}^{-1}$ sed DW, in the Day and Night experiment respectively) from the sampling site $(0-0.5 \mathrm{~cm}$ bsf) [30] and fixed diel and tidal rhythms were applied. The core sampling was carried out at low tide (1 PM, Figure 5.b) in the two mesocosms five days after MPB inoculation at the maximum MPB biofilm growth period. Three cores were randomly harvested from each mesocosm and treated as biological replicates, and the corresponding 5 layers were collected separately. All abiotic and biotic parameters were analysed from the three replicate cores at each depth in the two mesocosms as described below except for RNA extraction (two cores were used as biological duplicates). 
a)

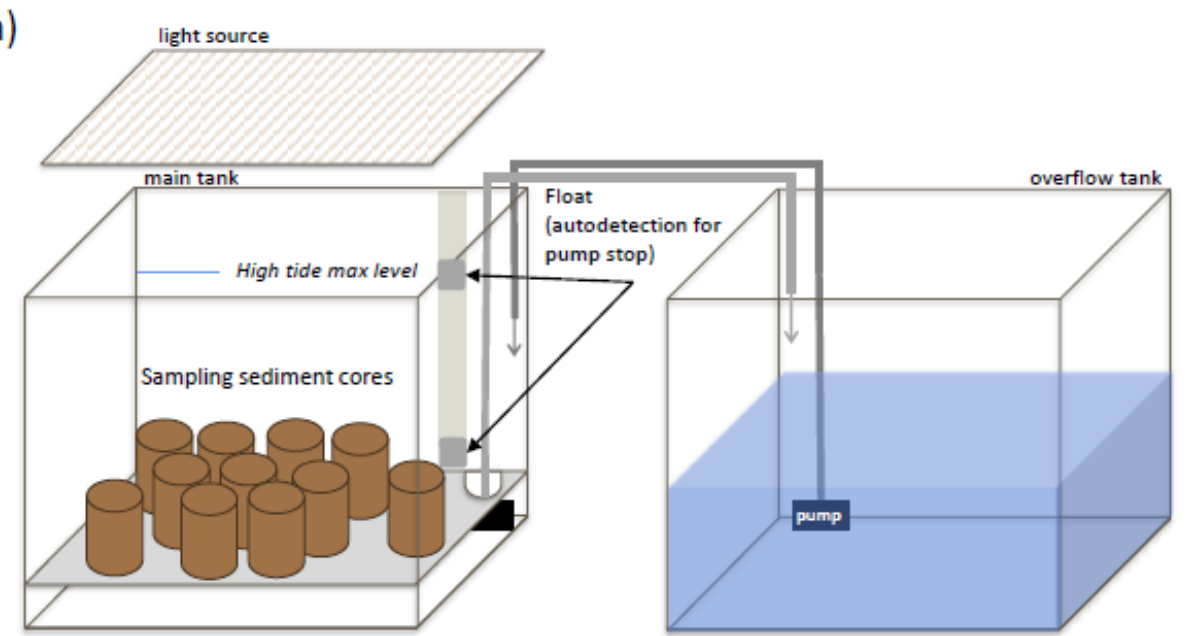

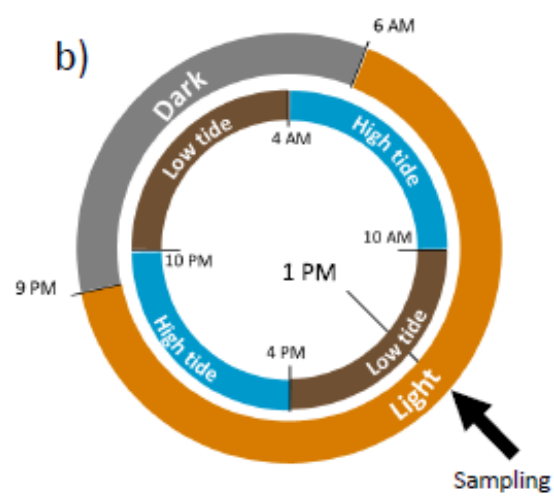

Day

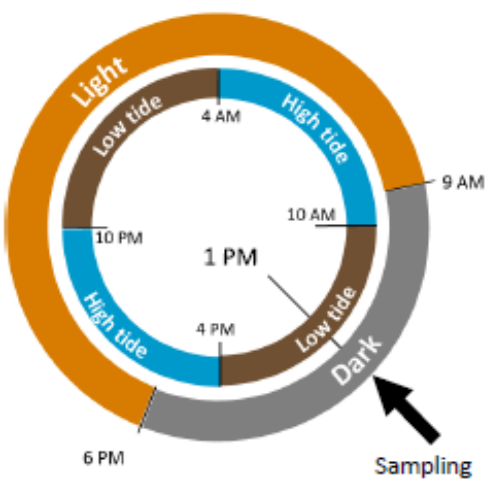

Night

Figure 1. Schematic view of the experimental design. a) One mesocosm consisted of two tanks: a main and overflow tank; b) schedule for the Day and Night mesocosms.

\subsection{Abiotic and biotic parameters}

The depth temperature profiles were measured with five 3.1-cm-length Hobo sensors (Hobo Pro V2, Bourne, Massachusetts, USA) fixed on a homemade stick that was vertically pushed into a specific sediment core to stabilize the sensors at 5 depths $(0.5 \mathrm{~cm}, 1 \mathrm{~cm}, 2 \mathrm{~cm}, 5 \mathrm{~cm}$ and $10 \mathrm{~cm}$ below the sediment surface).

The pore water $\mathrm{pH}$ and salinity were immediately measured on a supernatant after sediment centrifugation $\left(15 \mathrm{~min}, 3000 \times \mathrm{g}\right.$ at $8^{\circ} \mathrm{C}$ ) with a $\mathrm{pH}$ probe (Eutech Instruments PC150, Landsmeer, The Netherlands) and a conductivity meter (Cond 3110, TetraCon 325, WTW, Weilheim, Germany), respectively. 
The chlorophyll $a$ concentration ( $\mathrm{Chl} a$ ), used as a proxy of algal biomass, was quantified with fluorimetry (640 nm, Turner TD 700, Turner Designs, USA) using $50 \mathrm{mg}$ of freeze-dried sediment extracted in the dark at $+4^{\circ} \mathrm{C}$ with $90 \%$ acetone (mixed by repeatedly turning) and centrifuged (10 min, $\left.3500 \times \mathrm{g},+8^{\circ} \mathrm{C}\right)$. The $\mathrm{Chl} a$ concentrations were expressed as $\mu \mathrm{g} \mu \mathrm{g}^{-1}$ sediment dry weight (DW) according to Lorenzen [31].

\subsection{RNA extraction}

RNA was extracted for each depth from two biological duplicate cores of the two mesocosms $(n=20)$ with $5 \mathrm{~g}$ of liquid nitrogen-frozen sediment using a Power Soil ${ }^{\mathrm{TM}}$ Total RNA Isolation Kit (MOBIO, CA, USA) following the manufacturer's recommendations. Isolated RNAs were quantified using fluorimetry (NanoDrop, ND-800, Thermo Scientific, USA). The RNA samples were tested for the presence of contaminating genomic DNA using PCR (b341F518R for Bacteria [32] and 931F-M1100r for Archaea [33]; Online Resource Table S1) and then reverse transcribed with random hexamers using SuperScript III (Invitrogen, Life Technologies, USA).

\subsection{Pyrosequencing and bioinformatic analysis}

Amplification of the $\mathrm{V} 3-\mathrm{V} 5$ region of the $16 \mathrm{~S}$ rRNA transcripts was performed for all the extracted samples $(n=20)$ using the following primer set: for Bacteria $563 \mathrm{~F}$ and $907 \mathrm{R}$ [34] and for Archaea 519F [35] and 915R [36] (Online Resource Table S1). Libraries were created for all five layers and the two mesocosms (the duplicates were pooled before sequencing, $n=$ 10). Pyrosequencing was accomplished using the GATC platform (Konstanz, Germany) with a Roche 454 GS-FLX system with titanium chemistry. All of the sequences were checked against the following quality criteria: (i) no Ns; (ii) quality score $\geq 27$ and $>30$ for Bacteria and Archaea, respectively, according to the PANGEA process [37]; (iii) a minimum sequence length of $200 \mathrm{bp}$; and (iv) no sequencing error in the forward primer. After removing the primer sequence, the putative chimeras were detected using UCHIME [38]. The remaining 
reads were clustered at 97\% similarity threshold [39] with UCLUST [40]. The representative operational taxonomic units (OTUs) were used to build phylogenetic trees with FASTTREE [41] for the main taxonomic groups with reference sequences. These references were extracted to the SSUREF SILVA 119 [42] according to the following criteria: length $>1200$ bp, quality score $>75 \%$ and a pintail value $>50$. The taxonomic annotation was conducted with the nearest neighbour $(\mathrm{NN})$ method. This process was implemented in the pipeline $\begin{array}{llll}\text { Phylogenetic Analysis of Next-generation AMplicons (PANAM } & \end{array}$ https://github.com/panammeb/) and is described more in detail in a related study [43]. To retain and compare the largest possible number of samples, the datasets were resampled down to 13,000 and 800 sequences for Bacteria and Archaea, respectively (normalization process). The resulting datasets consisted of 25,600 OTUs (at 97\% threshold) for Bacteria and 1,065 OTUs (at 97\% threshold) for Archaea. Singletons and plastids were removed for further analyses resulting in a dataset containing 9,664 bacterial OTUs and 465 archaeal OTUs

\subsection{Statistical analysis}

All values are presented as the mean ( \pm standard error), and statistical analyses were performed with R software ( $\mathrm{R}$ Core Team, 2013). The most influential environmental parameters measured driving both the bacterial and archaeal OTU97-relative-abundance dataset were identified using a forward selection procedure [44] with the function forward.sel in the package 'packfor' [45].

A multiple factor analysis (MFA) was performed [46] using the package FactoMineR [47] to evaluate the distribution of bacterial and archaeal 16S rRNA transcript relative abundance (Online Resource Figure S1). The overall analysis involved a principal component analysis (PCA) applied to the entire table, in which each column of group $i$ was standardized by the inverse of the first eigenvalue of the separate PCA of group $i$. Thus, the MFA was run using normalized bacterial and archaeal relative abundance (through the 16S rRNA transcripts 
abundance) datasets as 2 different groups of variables. The 16S rRNA transcript distributions in both bacterial and archaeal datasets were not impacted by the normalization process (Procrustes correlation=0.98, $\mathrm{P}<0.01$ ) by the removal of either plastids or singletons (Procrustes correlation=0.94-0.98, $\mathrm{P}<0.01$ ). A third group of variables, containing the plastid abundance (resulting from sequencing dataset) and significant environmental parameters identified by the forward selection, was then added as additional variables to the MFA final ordination (Online Resource Table S2).

Additionally, to explore the mean influence of a given factor (i.e., sediment depths), we decomposed the total inertia (Online Resource Figure S1) of the standardized table using between- and within-class analyses with the functions dudi.pea, bca and wca in the 'ade4' package [48].

\section{Results}

4.1 Experimental conditions at low tide in the daytime mesocosm (Day) and night-time mesocosm (Night)

In the sediment surface, the photosynthetic active radiation was $231 \mu \mathrm{mol}$ photons $\mathrm{m}^{-2} \mathrm{~s}^{-1}$ ( $\pm 46 \mu \mathrm{mol}$ photons $\mathrm{m}^{-2} \mathrm{~s}^{-1}$ ) during the simulated daytime low tide. The ambient temperature varied between daytime and night-time due to light warming, and the mean temperature was $31.2^{\circ} \mathrm{C}\left( \pm 6.3^{\circ} \mathrm{C}\right)$ and $20.2^{\circ} \mathrm{C}\left( \pm 0.7^{\circ} \mathrm{C}\right)$, respectively. The sediment temperature was $25.7^{\circ} \mathrm{C}$ $\left( \pm 0.3^{\circ} \mathrm{C}\right)$ during the Day and $19.9^{\circ} \mathrm{C}\left( \pm 0.1^{\circ} \mathrm{C}\right)$ during the Night experiment (Online Resource Figure S2). The salinity varied from $32.0( \pm 0.2)$ (Day) to $30.5( \pm 0.3)$ (Night), and the pH exhibited depth variations ranging from 6.8 to 7.6 in both Day and Night (Online Resource Figure S2). 


\subsection{Microphytobenthic biofilm}

Microphytobenthic biomass and potential activity was estimated through the quantification of chlorophyll $a$ concentration (Online Resource Figure S2) and a record of 16S rRNA plastid transcripts, respectively. In the surface sediment (upper $0.5 \mathrm{~cm}$ ), the chlorophyll $a$ concentration was higher in the Day treatment $\left(173.6 \pm 20.8 \mu \mathrm{g} \mathrm{g}^{-1}\right.$ sed DW) than in the Night treatment $\left(90.1 \pm 4.2 \mu \mathrm{g} \mathrm{g}^{-1}\right.$ sed DW). These surficial concentrations represent an increase of $46 \%$ and $3 \%$ of chlorophyll $a$ content during Day and Night experiments, respectively, compared to the initial concentration of chlorophyll $a$ added in each experiment. Then, the chlorophyll $a$ concentration decreased with increasing depth, (i.e., $28 \mu \mathrm{g} \mathrm{g}^{-1}$ sed DW after 2 $\mathrm{cm}$ below sediment surface (bsf, Online Resource Figure S2). This result could be congruent with a lower relative abundance of $16 \mathrm{~S}$ rRNA transcript plastids-affiliated sequences in the Night treatment. During the Day exposure, these plastid-related sequences were abundant between 0 and $1 \mathrm{~cm}$ bsf, representing $56.7 \%$ of relative abundance of $16 \mathrm{~S}$ rRNA transcript plastids-affiliated sequences in comparison to $39.4 \%$ during the Night exposure.

\subsection{A specific distribution of potentially active bacterial and archaeal community structures revealed by a multiple factor analysis}

A forward selection of 17 environmental variables highlighted the factors explaining a significant part of differences in bacterial and archaeal transcript diversity. The bacterial $16 \mathrm{~S}$ rRNA transeript distribution was better explained by chlorophyll $a$ and phosphate concentrations while archaeal 16S rRNA transcript distribution was better explained by depth and $\mathrm{pH}$ (Online Resource Table S2). Then, a multiple factor analysis (MFA) was used to investigate the distribution of both bacterial and archaeal 16S rRNA transcripts (Figure 6 and Online Resource Figure S2). The first dimension of the ordination discriminated the 5 sediment layers from the surface to deep layers (Figure 6.a). A between-class analysis coupled to the MFA revealed that than $66 \%$ of the total MFA inertia was due to sediment 
depth rather than Day/Night exposure, indicating that the diversity of both bacterial and archaeal 16S rRNA transcripts was largely structured along a vertical gradient in the sediments (Figure 6). This diversity was almost identical during the Day and Night treatments (5\% total MFA inertia explained by the Day/Night factor; Figure 6).

The bacterial taxa that contributed the most to the first dimension were $\delta$ Proteobacteria (4.14\% contribution of the variable to the first dimension), Deferribacteres (3.80\%), environmental group (i.e., BHI80-139, Candidate division OD1, Candidate division OP3, Candidate division TM7, Candidate division WS3, EM19, GOUTA4, Hyd24-12, JLETNP-Z39, LD1-PA38, NPL-UPA2, TA06 and TM6) (3.64\%), Chloroflexi $(3.56 \%)$ and Armatimonadetes (3.13\%) (Online Resource Figure S3).

The archaeal taxa that contributed the most to the first dimension of the MFA were archaea group C3 (6.88\% contribution of the variable to the first dimension), Euryarchaeota Rice Cluster V (6.63\%), Euryarchaeota LDS group (5.92\%), Euryarchaeota Thermoplasmata (5.82\%), and Crenarchaeota Marine Benthic Group B (5.76\%) (Online Resource Figure S3). 


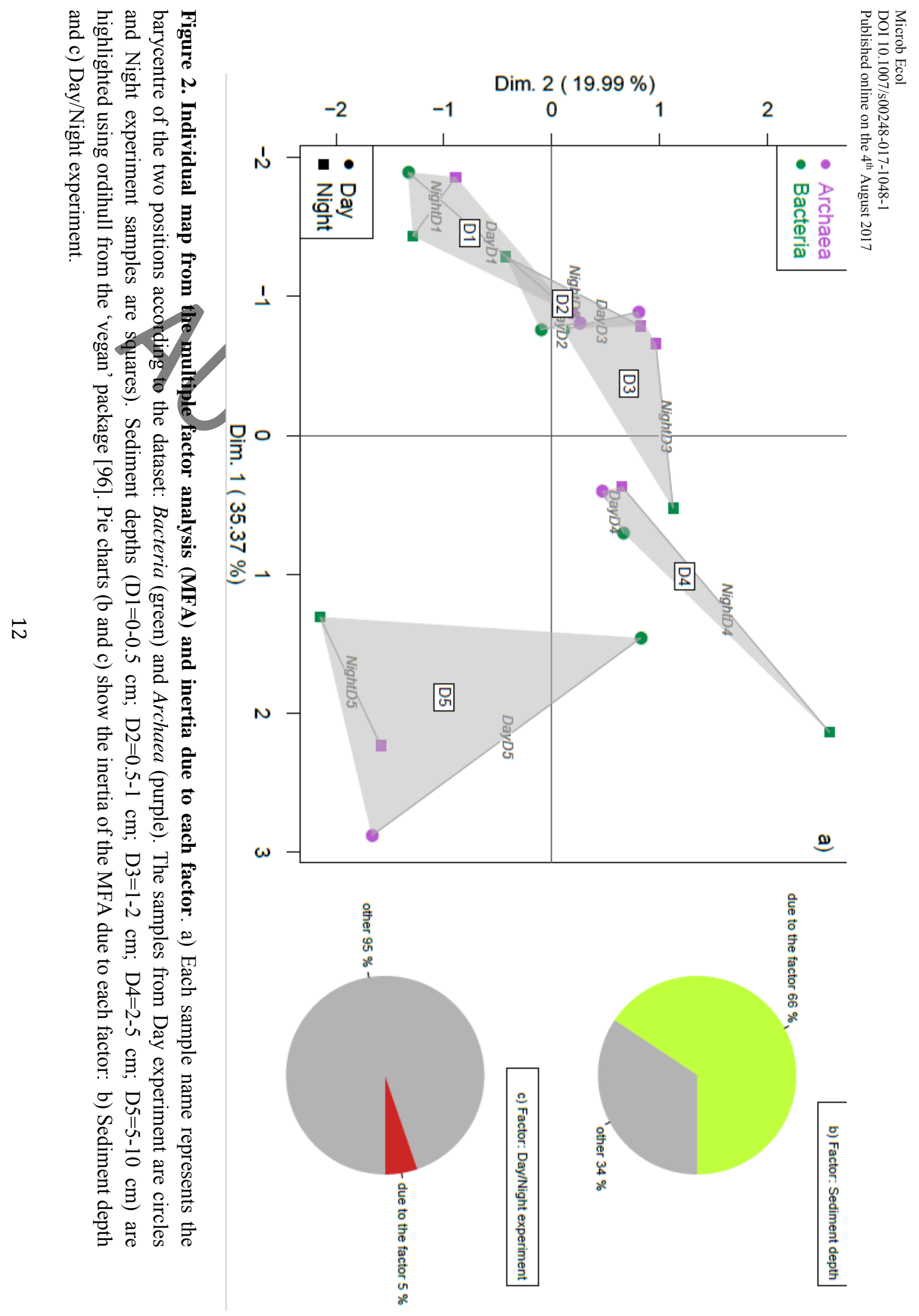


Microb Ecol

DOI 10.1007/s00248-017-1048-1

Published online on the $4^{\text {th }}$ August 2017

\subsection{Bacterial 16S rRNA transcript diversity}

Coverage ranged from 71.8 to $88.4 \%$, with maximum coverage recorded at the surface. Both the coverage values (Online Resource Table S3) and rarefaction curves (Online Resource Figure S4.a) indicated that we assessed a large part of the active bacterial community. Chao1 index indicated that richness was higher in lower sediment layers (i.e., from 1-10 $\mathrm{cm}$ below the sediment surface) than in the upper one (i.e., from $0-1 \mathrm{~cm} \mathrm{bsf}$ ) during the Day exposure (Online Resource Table S3). During the Night exposure, richness was higher (from 11625 to 13709 estimated OTUs) from 1 to $5 \mathrm{~cm}$ bsf (Online Resource Table S3).

After the removal of singletons and plastid-related sequences, the bacterial dataset consisted of 9,663 OTUs (represented by 87,805 sequences). Bacterial sequences were related to 42 phyla affiliated with Proteobacteria, Planctomycetes, Firmicutes and Acidobacteria $(65.63 \%, 5.36 \%, 4.16 \%, 3.08 \%$ of the sequences, respectively, Figure 7$)$.

The Proteobacteria transcript abundance ranged from 54.04 to $77.22 \%$ of the sequences. Together, the $\gamma$-Proteobacteria and the $\delta$-Proteobacteria dominated the proteobacterial assemblage (from 70.94 to $82.17 \%$ of the proteobacterial-affiliated sequences). The $\gamma$-Proteobacteria represented $38.90 \%$ of the proteobacterial-affiliated sequences and were mainly retrieved in the sediment surface, from 0 to $2 \mathrm{~cm} \mathrm{bsf}$, with the exception of the Night treatment between 5 and $10 \mathrm{~cm}$ bsf. The $\delta$-Proteobacteria represented $36.86 \%$ of the total proteobacterial sequences and were mainly retrieved in the deeper horizon (from 2 to $10 \mathrm{~cm}$ bsf). The $\alpha$-Proteobacteria sequences were less abundant, accounting for 13.76 to $22.26 \%$ of the proteobacterial sequences, and their abundances were maximal from 1 to $5 \mathrm{~cm}$ bsf. The $\beta$ - and $\varepsilon$-Proteobacteria, were represented by less than $5 \%$ of the total proteobacterial sequences (Figure 7).

Planctomycetes abundance ranged from 3.40 to $8.55 \%$ of the transcript relative abundance in each sample, except for the Day treatment's surficial sediments $(0-0.5 \mathrm{~cm}$ bsf), 
in which they represented only 1.64\%. Planctomycetes consisted in Phycisphaerae (43.86\%) and Planctomycetacia (18.07\%). A large portion of the Planctomycetes-affiliated sequences fell into environmental groups such as the vadinBA30 marine sediment group. Interestingly, no anammox-like Planctomycetes (Brocadiales) were recorded in our dataset.

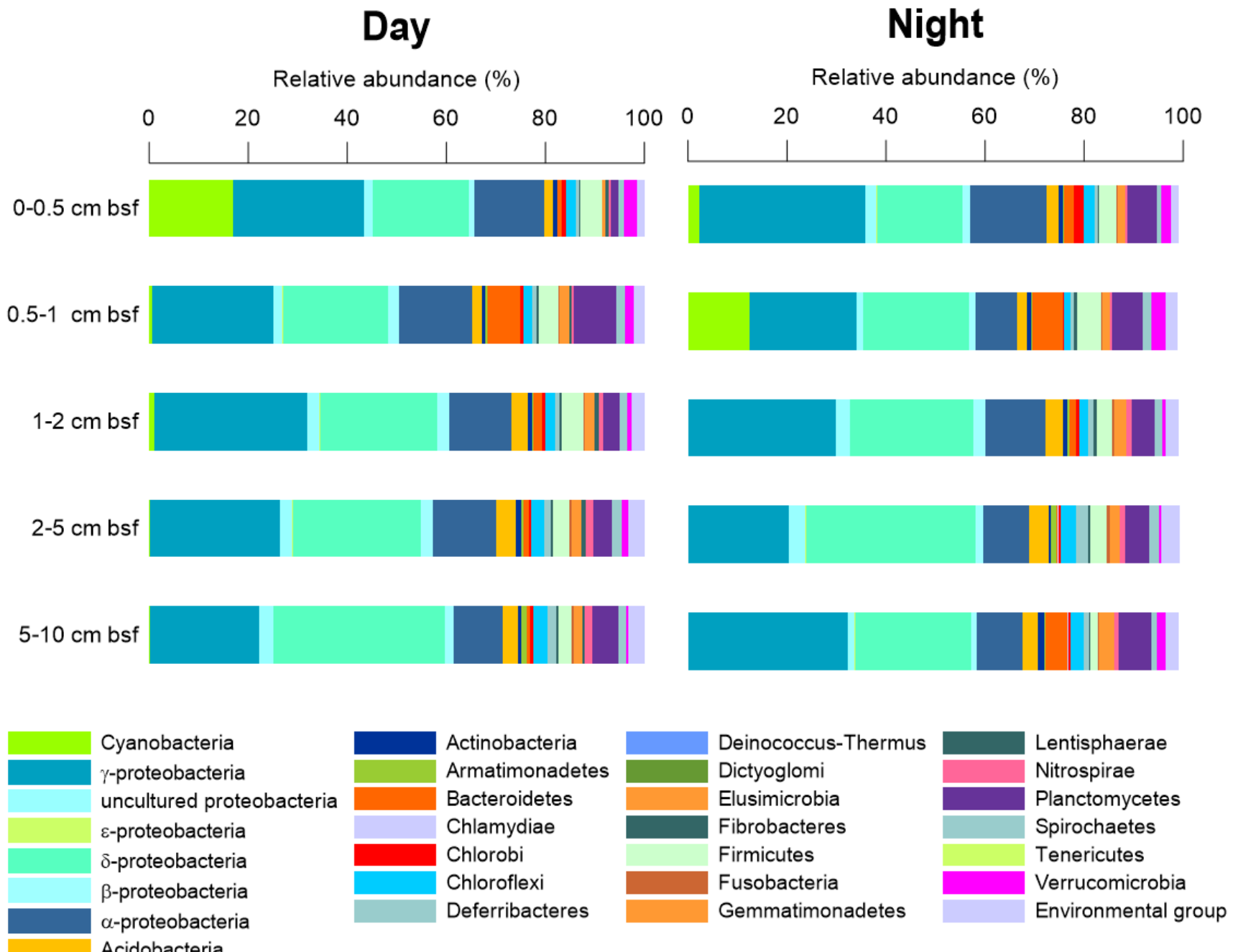

Figure 3. Distribution of bacterial 16S rRNA transcripts. The relative abundance of the $16 \mathrm{~S}$ rRNA transcripts and the affiliation of the total bacterial operational taxonomic units (OTUs 97\%) at the phylum level (except for Proteobacteria, class level) between the two Day and Night treatments among the five layers below the sediment surface (bsf). Environmental group contained BHI80-139, Candidate division OD1, Candidate division OP3, Candidate division TM7, Candidate division WS3, EM19, GOUTA4, Hyd24-12, JL-ETNP-Z39, LD1PA38, NPL-UPA2, TA06 and TM6. Note that plastids originated from microalgae were removed from the dataset. 


\subsection{Archaeal $16 S$ rRNA transcript diversity}

For the archaeal 16S rRNA transcripts dataset, the rarefaction curves indicated that the sequencing depth captured almost all of the diversity present in the natural community (Online Resource Figure S4.b). Chao1 index showed that during both the Night and Day exposures, sediment layers from 1 to $2 \mathrm{~cm}$ below the surface, richness was higher (Online Resource Table S2). Archaeal sequences were affiliated with Thaumarchaeota, Crenarchaeota, Bathyarchaeota (all part of the TACK superphylum [49]) and Euryarchaeota (Figure 8).

Between 0 and $5 \mathrm{~cm}$ bsf, Thaumarchaeota dominated the potentially active archaeal assemblage (from 53 to $83 \%$ of the transcript abundance). Thaumarchaeota were mainly represented by Marine Group I (MGI), ranging from 4.96 to $83.20 \%$ of the total transcript number, in the deeper and the surface layers, respectively. To a lesser extent, Halobacteriales were retrieved, ranging from 3.01 to $23.61 \%$ of the total transcript number, and the poorly known Rice Cluster V was represented from 0.79 to $9.44 \%$ of the total transcript abundance, with maximal occurrence in the surficial horizon (between 0 and $5 \mathrm{~cm} \mathrm{bsf}$ ).

Between 5 and $10 \mathrm{~cm}$ bsf, a contrasting picture was observed, with a decrease in the abundance of the thaumarchaeal transcripts (less than $12.2 \%$ of the total sequences) in favour of the archaeal group C3 (from 73.6 to $77.8 \%$ ), also called MCG15 [50]. 


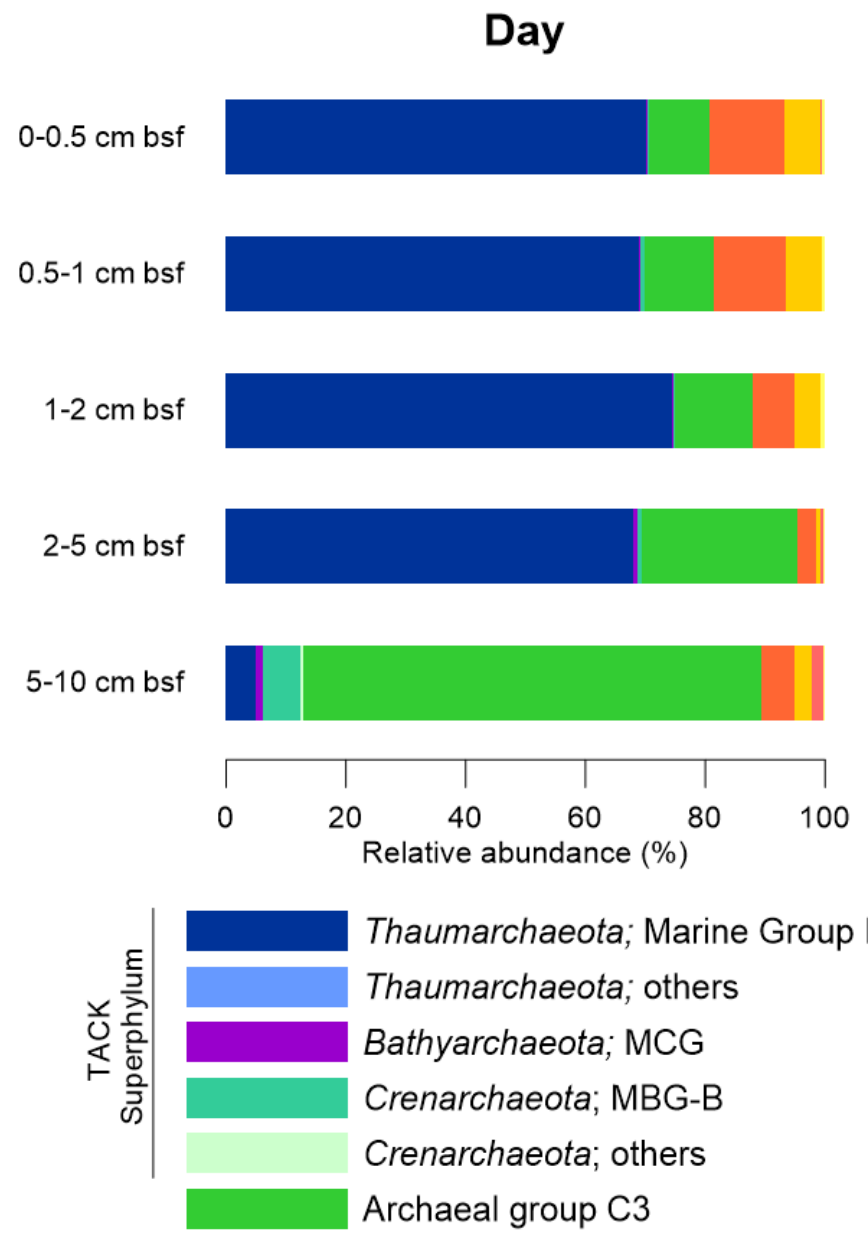

Night
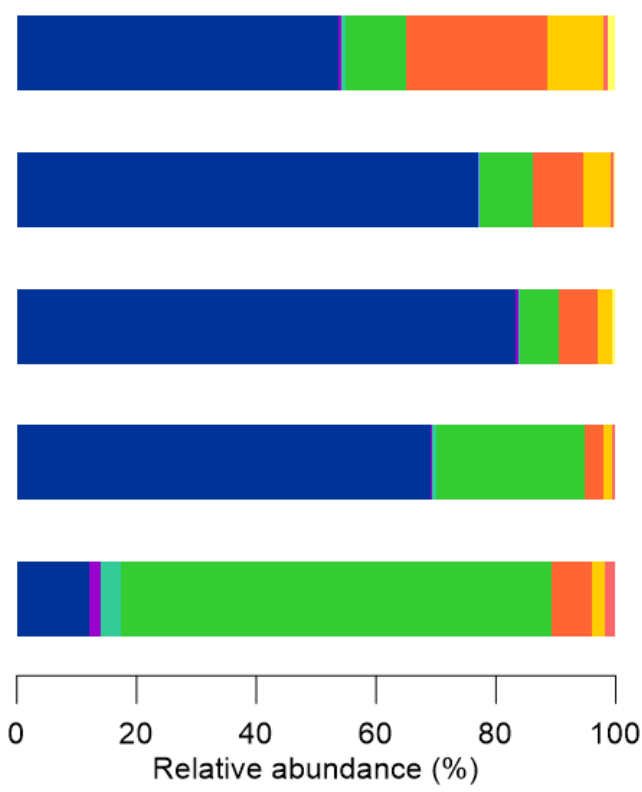

Euryarchaeota; Halobacteria

Euryarchaeota; Rice Cluster V

Euryarchaeota; Thermoplasmata

Euryarchaeota; LDS group

Euryarchaeota; Methanomicrobia

Figure 4. Distribution of archaeal 16S rRNA transcripts. The relative abundance of the $16 \mathrm{~S}$ rRNA transcripts and the affiliation of the total archaeal operational taxonomic units (OTUs 97\%) at the class level between the two Day and Night treatments among the five layers below the sediment surface (bsf).

\section{Discussion}

Previous research has reported that temperature and salinity impact the microbial communities in marine systems [51] and global surveys have attempted to explore the overall microbial diversity and distribution in oceans [52-54]. In this study, we have developed an original tidal mesocosm experiment to explore the effect of diel rhythms and/or sediment depth on the relative abundance of both bacterial and archaeal 16S rRNA transcripts originating from five sediment depths of an intertidal mudflat incubated at two different conditions. This work highlighted a greater impact of sediment depth rather than diel cycle on 
potentially active prokaryotes in intertidal sediments colonized by a microphytobenthic biofilm. While experimental studies such as mesocosms do not replicate environmental conditions exactly, they consisted in valuable systems to simplify complex environments. By controlling specific environmental variables, mesocosms experiments allowed investigating local-scale community dynamics [28] but also elucidating microbial response to the given test conditions. In the present work, the similarity between Day and Night in terms of $\mathrm{pH}$ or prokaryotic abundance may indicate that there was no tank-induced variation and that the system was valuable for investigating the impact of specific factors.

One important issue of the procedure used for this mesocosm experiment was that the cores used in this study were not kept intact from the field as macrofauna was removed by sieving the sediment by depth and the cores were then reassembled. This uncommon reassembling procedure inspired by Michaud et al. [29] allows a faster recovery of nutrient vertical profiles. While it could affect the diversity of bacterial and archaeal $16 \mathrm{~S}$ rRNA transcripts, the core reassembly procedure may impact both Day and Night cores by the same way and thus do not interfere in the interpretation of the results.

The results indicated that microphytobenthic (MPB) abundances decreased with depth according to light penetration (data not shown) and oxygen content (representing from 39 to $60 \%$ of the bacterial transcript relative abundance between 0 and $1 \mathrm{~cm}$ bsf and representing less than $20 \%$ of bacterial transcript relative abundance from 1 to $10 \mathrm{~cm} \mathrm{bsf}$ ). The best blast match of these plastid transcripts sequences suggests that the microphytobenthic communities mainly belong to the diatom order Naviculales (nblast best hits: AF514848, AF514855, AF514847; Poulin et al. [55]). Interestingly, during the Night exposure, the plastids were primarily retrieved from 0.5 to $1 \mathrm{~cm}$ bsf, suggesting that the diatoms might not migrate to the sediment surface. This phenomenon may have resulted in the absence of the vertical 
migration of MPB in the mesocosm system during night, which is congruent with a peak in cell division in the aphotic zone of the sediment [26].

This study highlighted that bacterial and archaeal 16S rRNA transcript diversity used as a proxy of potentially active bacterial and archaeal community layout is not modified by the diel cycle. The use of this proxy should be interpreted with caution considering the environmental parameters and specific taxa due to some inconsistent relationships between 16S rRNA and activity [56]. However, previous work reported the value of examining communities at the $16 \mathrm{~S}$ rRNA transcripts $[57,58]$. The multiple factor anatysis (MFA) indicated that the diel rhythm had a weak effect on both potentially active Archaea and Bacteria (5\% total inertia, Figure 6.c), and that the prokaryotic communities were mainly shaped by sediment depth (66\% of total inertia of the MFA, Figure 6.b). These issues are crucial because it means that a same pool of microorganisms incubated in two mesocosms and sampled at two different conditions did not follow a neutral random distribution but can exhibit a similar active organization with vertical-driven assemblages. A limited number of archaeal and bacterial phyla, including the Proteobacteria, Thaumarchaeota Marine Group I, Euryarchaeota Rice Cluster V, or Group C3, explained a large part of the variance and thus, represented the key phyla in the vertical assemblage distribution. This vertical configuration could be the reflection of microorganism adaptation and cooperation facing to their environment. The forward selection of the most influential environmental parameters (Online Resource Table S2) revealed that potentially active Bacteria were mainly influenced by the chlorophyll $a$ and phosphate concentrations. Interestingly, the phosphate concentrations was already found to be an important factor influencing enzymatic activities and abundance of prokaryotes in the same intertidal mudflat [59]. In the current study, phosphate concentrations were correlated with bacterial taxa mainly retrieved in deeper layers between 2 and $10 \mathrm{~cm}$ bsf and this could be related to a phosphate release by some proteobacterial taxa [60]. Data 
obtained in the present work suggested that archaeal 16S rRNA transcript relative abundances were mainly related to the $\mathrm{pH}$ in the sediments. However, the lack of cultured representative for many bacterial and archaeal environmental groups limits the physiology characterization of their adaptive abilities.

Proteobacteria largely dominated the potentially active bacterial assemblage, with most of the 16S rRNA transcript sequences affiliated with $\delta$-, $\gamma$ - and $\alpha$-Proteobacteria. The retrieval of $\delta$-Proteobacteria has been largely reported in coastal and estuarine sediments [52, 61], and may also be potentially active in intertidal mudflats. Moreover, the retrieval of OTUs affiliated with Desulfobacteraceae (from $0.82 \%$ to $8.02 \%$ ) and Desulfobulbaceae (from $0.72 \%$ to $7.04 \%$ ), which are known to be involved in the sulfur cycle [62], supports the idea that this biogeochemical cycle is important in intertidal sediments. Indeed, some are commonly retrieved in sedimentary ecosystems [63], whereas others, such as Desulfobulbus, could oxidize sulfide through a filamentous cable [64]. Sequences affiliated with the unclassified Desulfuromonadales were also retrieved in the present work, and this environmental group has been previously reported in contaminated sediments and has in some cases been strongly correlated with heavy metals such as $\mathrm{Fe}, \mathrm{Cu}$ and $\mathrm{Cr}$ [61]. Among the $\gamma$ Proteobacteria, most of the sequences were related to the Dasania genus, even in the lower anoxic sediment samples (between 5 and $10 \mathrm{~cm}$ bsf), although this genus is known to contain obligatory aerobic Bacteria [65]. Thus, we hypothesized that this lineage might have developed tolerance mechanisms to anoxia or might contain phylotypes that are able to grow in anaerobic conditions.

Our study also indicates the importance of potentially active Planctomycetes [66]. These Bacteria inhabit aquatic and terrestrial ecosystems but also inhabit ultra-dry soils [67], marine stromatolites [68], acid peat bogs [69] and hot springs [70]. In recent decades, this lineage has become of specific interest for microbial ecologists because these taxa have been 
determined to be important players in the nitrogen cycle through anaerobic ammonia oxidation [71-75]. However, anammox-like Brocadiales were not found in our dataset and qPCR based analyses on $h s z A$ gene did not provide evidence of anammox process in this work (data not shown) which are congruent with previous work showing that all Planctomyctes were not implicated in this process [75].

Our study also suggested the presence of potentially active Firmicutes. Related transcript sequences were affiliated with gut commensal groups such as Ruminococcaceae and Lachnospiraceae. However, in a large study, Zinger et al. [52] also reported this type of Bacteria in coastal sediments and hypothesized a terrestrial origin. This terrestrial-related group may be dispersed by episodic events such as river flooding, storms or discharge from the catchment area before sampling for the experiment occurred.

Considering potentially active archaeal assemblages, a clear segregation was observed between 0 and $5 \mathrm{~cm}$ bsf where Thaumarchaeota 16S rRNA transcript numbers dominated (6.9-26.4\% transcripts), while from 5 to $10 \mathrm{~cm}$ bsf the archaeal group C3 dominated (73.6$77.8 \%$ transcripts). In this study, each sample was extracted in duplicates and then pooled before sequencing. Whife replicates should give robustness at the findings, all the issues of this study are congruent as Day and Night experiments were very similar and confirmed that the diversity described is reliable. As an important evidence this strong shift in archaeal $16 \mathrm{~S}$ rRNA transcript diversity was observed in the two independent Day and Night experiments.

The Thaumarchaeota Marine Group I is involved in the nitrification process in diverse ecosystems such as deep waters [76-78], estuarine and coastal waters [57, 79, 80], marine sediments $[81,82]$, lakes $[83,84]$, and soils $[85,86]$. The abundance of Thaumarchaeota transcripts in the sediment of an intertidal zone strengthened the idea that the nitrogen cycle is of main influence in this environment $[87,88]$. This finding was congruent with the increase in nitrate, which is the final product of nitrification, from $0-5 \mathrm{~cm}$ bsf. Moreover, previous 
studies conducted in microcosm experiments in a French mudflat [89] indicated a dominance of potentially active Bathyarchaeota or Miscellaneous Crenarchaeotic Group (MCG) [90] and contrasted with another study conducted in a peatland in which an archaeal active assemblage was dominated by methanogens [91]. In our study, the archaeal group C3 dominated from 5 to $10 \mathrm{~cm}$ bsf (73.6-77.8\% transcripts). Several recent studies have reported its presence in hydrothermal vents $[92,93]$, methane seeps, cold seeps [94, 95], estuarine sediments [89] and lakes [84]. Although this group has been retrieved in diverse environments, it has rarely been recorded as abundant or active in any ecosystem. Despite the ubiquity of the archaeal group $\mathrm{C} 3$ in various sediments, little is known about its functional role in ecosystems.

\section{Conclusion}

Coastal sediments exhibit some of the highest levels of microbial diversity in the marine realm because they are located at the interface of terrestrial, aerial and aquatic systems and are nutrient-rich environments with a large proportion of anoxic/oxic niches. In intertidal systems, the inhabiting prokaryotes can be subjected to extreme changes in environmental conditions, leading to strong modifications of their metabolism. In particular, over a 24-h period, both the diel and tidal rhythms influence the photosynthesis process enacted by benthic micro-algae (i.e., microphytobenthos), thus driving the availability of oxygen and photosynthesis-derived products. In this context, using a tidal mesocosm, we demonstrated that this diel cycle did not impact the bacterial and archaeal 16S rRNA transcript diversity. Active Bacteria and Archaea were diverse, suggesting the capacity of this system to promote diverse ecosystem functions. Our work indicates that Bacteria and Archaea organize themselves in specific active assemblages vertically along sediment depth independently of diel fluctuations. These specific active assemblages were recorded with predominance of taxa such as Thaumarchaeota MGI or $\delta$-Proteobacteria Desulfobulbus involved in nitrogen and 
DOI 10.1007/s00248-017-1048-1

Published online on the $4^{\text {th }}$ August 2017

sulfur cycles, respectively. We thus hypothesize that the nitrogen and sulfur cycles may influence the presence of these specific active assemblages in a stringent zone where organic matter is less labile in order to maintain competitiveness. This work also highlighted the importance of considering less characterized groups, such as the archaeal C3 group that may be important factors in ecosystem functioning.

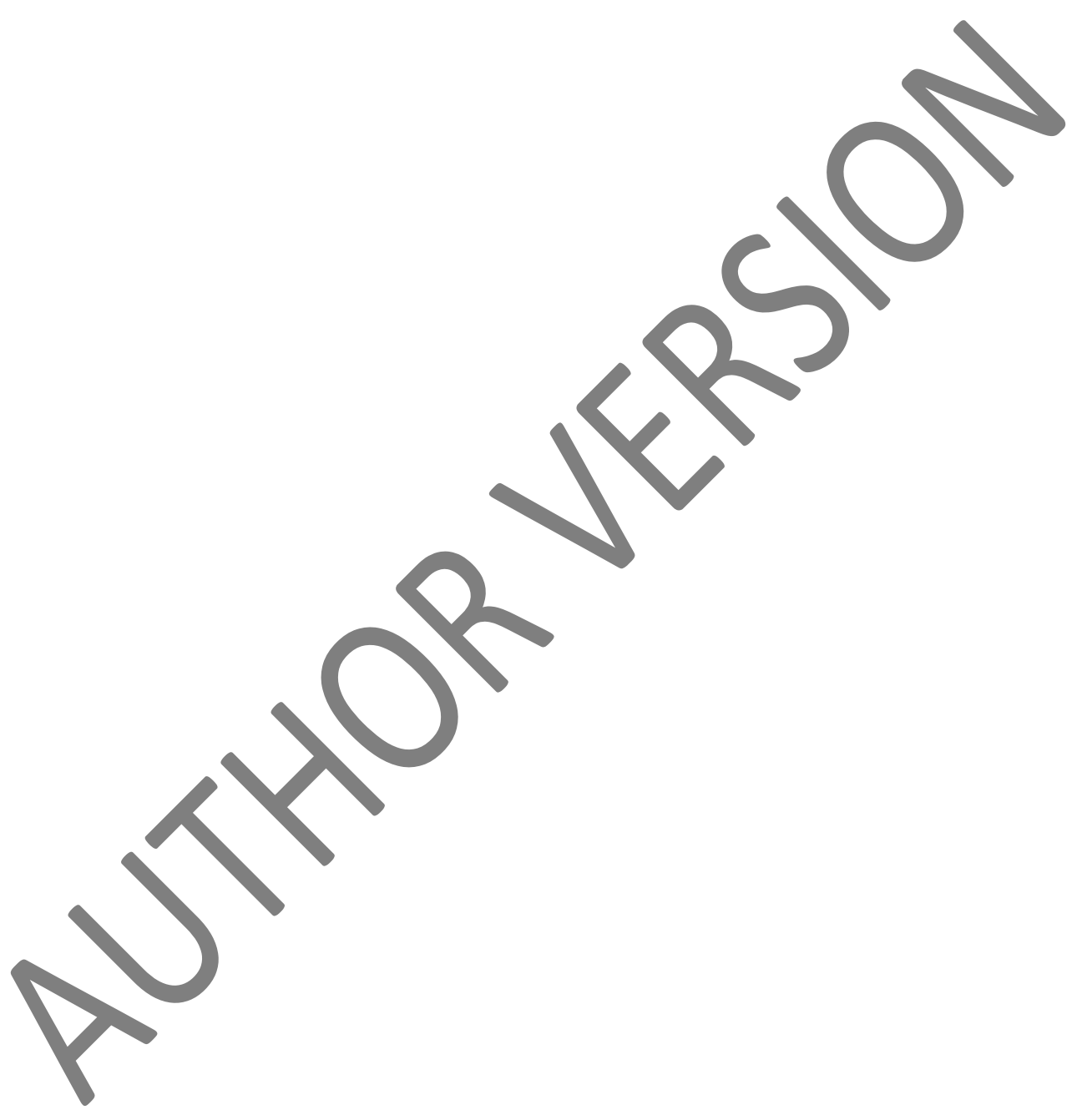




\section{References}

1. Kirchman DL, Dittel AI, Malmstrom RR, Cottrell MT (2005) Biogeography of major bacterial groups in the Delaware Estuary. Limnol Oceanogr 50:1697-1706.

2. Böer S, Hedtkamp SI, van Beusekom JE, et al (2009) Time- and sediment depth-related variations in bacterial diversity and community structure in subtidal sands. ISME J 3:780-791. doi: 10.1038/ismej.2009.29

3. Herlemann DPR, Labrenz M, Jurgens K, et al (2011) Transitions in bacterial communities along the $2000 \mathrm{~km}$ salinity gradient of the Baltic Sea. ISME J 5:15711579. doi: http://www.nature.com/ismej/journal/v5/n10/suppinfo/ismej201141s1.html

4. Liu J, Yang H, Zhao M, Zhang XH (2014) Spatial distribution patterns of benthic microbial communities along the Pearl Estuary, China. Syst Appl Microbiol 37:578589. doi: 10.1016/j.syapm.2014.10.005

5. Gobet A, Boer S, Huse SM, et al (2012) Diversity and dynamics of rare and of resident bacterial populations in coastal sands. ISME J 6:542-553. doi: 10.1038/ismej.2011.132

6. Consalvey M, Paterson DM, Underwood GJC (2004) The ups and downs of life in a benthic biofilm: migration of benthic diatoms. Diatom Res 19:181-202. doi: $10.1080 / 0269249 \times .2004 .9705870$

7. Ritzrau W, Graf G (1992) Increase of microbial biomass in the benthic turbidity zone of Kiel Bight after resuspension by a storm event. Limnol Oceanogr 37:1081-1086. doi: 10.4319/1o.1992.37.5.1081

8. Friend PL, Collins MB, Holligan PM (2003) Day-night variation of intertidal flat sediment properties in relation to sediment stability. Estuar Coast Shelf Sci 58:663675. doi: http://dx.doi.org/10.1016/S0272-7714(03)00178-1

9. Friend PL, Lucas CH, Rossington SK (2005) Day-night variation of cohesive sediment stability. Estuar Coast Shelf Sci 64:407-418. 
10. Guizien K, Dupuy C, Ory P, et al (2014) Microorganism dynamics during a rising tide: Disentangling effects of resuspension and mixing with offshore waters above an intertidal mudflat. J Mar Syst 129:178-188. doi: 10.1016/j.jmarsys.2013.05.010

11. Harrison SJ, Phizacklea AP (1987) Vertical temperature gradients in muddy intertidal sediments in the Forth estuary, Scotland1. Limnol Oceanogr 32:954-963. doi: 10.4319/1o.1987.32.4.0954

12. Montagna P a., Bauer JE, Hardin D, Spies RB (1989) Vertical distribution of microbial and meiofaunal populations in sediments of a natural coastal hydrocarbon seep. J Mar Res 47:657-680. doi: 10.1357/002224089785076226

13. Edlund A, Hårdeman F, Jansson JK, Sjöling S (2008) Active bacterial community structure along vertical redox gradients in Baltic Sea sediment. Environ Microbiol 10:2051-2063. doi: 10.1111/j.1462-2920.2008.01624.X

14. Fan X, Xing P (2016) The Vertical Distribution of Sediment Archaeal Community in the "Black Bloom" Disturbing Zhushan Bay of Lake Taihu. Archaea. doi: $10.1155 / 2016 / 8232135$

15. Hewson I, Vargo GA, Fuhrman JA (2003) Bacterial diversity in shallow oligotrophic marine benthos and overlying waters: effects of virus infection, containment, and nutrient enrichment. Microb Ecol 46:322-336. doi: 10.1007/s00248-002-1067-3

16. Kristensen E (2000) Organic matter diagenesis at the oxic/anoxic interfacein coastal marine sediments, with emphasis on the role of burrowing animals. Hydrobiologia 124. doi: 10.1023/A:1003980226194

17. Laverock B, Gilbert JA, Tait K, et al (2011) Bioturbation: Impact on the marine nitrogen cycle. Biochem Soc Trans 39:315-320.

18. Passarelli C, Olivier F, Paterson DM, et al (2014) Organisms as cooperative ecosystem engineers in intertidal flats. $\mathrm{J}$ Sea Res 92:92-101. doi: 
http://dx.doi.org/10.1016/j.seares.2013.07.010

19. Risgaard-Petersen N (2003) Coupled nitrification-denitrification in autotrophic and heterotrophic estuarine sediments: On the influence of benthic microalgae. Limnol Oceanogr 48:93-105. doi: 10.4319/1o.2003.48.1.0093

20. Hochard S, Pinazo C, Grenz C, et al (2010) Impact of microphytobenthos on the sediment biogeochemical cycles: A modeling approach. Ecol Modell 221:1687-1701. doi: http://dx.doi.org/10.1016/j.ecolmodel.2010.04.002

21. Admiraal W (1984) The ecology of estuarine sediment inhabiting diatoms. Prog Phycol Res 3:269-314.

22. Blanchard GF, Guarini J-M, Orvain F, Sauriau P-G (2001) Dynamic behaviour of benthic microalgal biomass in intertidal mudflats. J Exp Mar Bio Ecol 264:85-100. doi: 10.1016/s0022-0981(01)00312-4

23. Underwood GJC, Paterson DM (2003) The importance of extracellular carbohydrate production by marine epipelic diatoms. Adv Bot Res 40:183-240. doi: 10.1016/S00652296(05)40005-1

24. Herlory O, Guarini J-M, Richard P, Blanchard G (2004) Microstructure of microphytobenthic biofilm and its spatio-temporal dynamics in an intertidal mudflat (Aiguillon Bay, France). Mar Ecol Prog Ser 282:33-44.

25. Haynes K, Hofmann TA, Smith CJ, et al (2007) Diatom-derived carbohydrates as factors affecting bacterial community composition in estuarine sediments. Appl Environ Microbiol 73:6112-6124. doi: 10.1128/aem.00551-07

26. Saburova MA, Polikarpov IG (2003) Diatom activity within soft sediments: behavioural and physiological processes. Mar Ecol Prog Ser 251:15-126.

27. Thornton DCO, Underwood GJ, Nedwell DB (1999) Effect of illumination and emersion period on the exchange of ammonium across the estuarine sediment-water 
interface. Mar Ecol Prog Ser 184:11-20. doi: 10.3354/meps184011

28. Lindström ES, Langenheder S (2012) Local and regional factors influencing bacterial community assembly. Environ Microbiol Rep 4:1-9. doi: 10.1111/j.17582229.2011.00257.x

29. Michaud E, Aller RC, Stora G (2010) Sedimentary organic matter distributions, burrowing activity, and biogeochemical cycling: Natural patterns and experimental artifacts. Estuar Coast Shelf Sci 90:21-34.

30. Agogué H, Mallet C, Orvain F, et al (2014) Bacterial dynamics in a microphytobenthic biofilm: A tidal mesocosm approach. J Sea Res 92:36-45. doi: 10.1016/j.seares.2014.03.003

31. Lorenzen CJ (1966) A method for the continuous measurement of in vivo chlorophyll concentration. Deep Res Oceanogr Abstr 13:223-227.

32. Muyzer G, de Waal EC, Uitterlinden AG (1993) Profiling of complex microbial populations by denaturing gradient gel electrophoresis analysis of polymerase chain reaction-amplified genes coding for 16S rRNA. Appl Environ Microbiol 59:695-700.

33. Einen J, Thorseth IH, Øvreås L (2008) Enumeration of Archaea and Bacteria in seafloor basalt using real-time quantitative PCR and fluorescence microscopy. FEMS Microbiol Lett 282:182-187. doi: 10.1111/j.1574-6968.2008.01119.x

34. Muyzer G, Teske A, Wirsen C, Jannasch H (1995) Phylogenetic relationships of Thiomicrospira species and their identification in deep-sea hydrothermal vent samples by denaturing gradient gel electrophoresis of $16 \mathrm{~S}$ rDNA fragments. Arch Microbiol 164:165-172. doi: 10.1007/bf02529967

35. Herfort L, Schouten S, Abbas B, et al (2007) Variations in spatial and temporal distribution of Archaea in the North Sea in relation to environmental variables. FEMS Microbiol Ecol 62:242-257. doi: 10.1111/j.1574-6941.2007.00397.x 
36. Casamayor EO, Massana R, Benlloch S, et al (2002) Changes in archaeal, bacterial and eukaryal assemblages along a salinity gradient by comparison of genetic fingerprinting methods in a multipond solar saltern. Environ Microbiol 4:338-348. doi: 10.1046/j.1462-2920.2002.00297.x

37. Giongo A, Crabb DB, Davis-Richardson AG, et al (2010) PANGEA: pipeline for analysis of next generation amplicons. Isme J 4:852-861. doi: 10.1038/ismej.2010.16

38. Edgar RC, Haas BJ, Clemente JC, et al (2011) UCHIME improves sensitivity and speed of chimera detection. Bioinformatics 27:2194-2200. doi: 10.1093/bioinformatics/btr381

39. Kim M, Morrison M, Yu Z (2011) Evaluation of different partial 16S rRNA gene sequence regions for phylogenetic analysis of microbiomes. J Microbiol Methods 84:81-87. doi: http://dx.doi.org/10.1016/j.mimet.2010.10.020

40. Edgar RC (2010) Search and clustering orders of magnitude faster than BLAST. Bioinformatics 26:2460-2461. doi: 10.1093/bioinformatics/btq461

41. Price MN, Dehal PS, Arkin AP (2009) Fasttree: Computing large minimum evolution trees with profiles instead of a distance matrix. Mol Biol Evol 26:1641-1650. doi: 10.1093/molbev/msp077

42. Pruesse E, Quast C, Knittel K, et al (2007) SILVA: A comprehensive online resource for quality checked and aligned ribosomal RNA sequence data compatible with ARB. Nucleic Acids Res 35:7188-7196. doi: 10.1093/nar/gkm864

43. Taib N, Mangot J-F, Domaizon I, et al (2013) Phylogenetic affiliation of SSU rRNA genes generated by massively parallel sequencing: new insights into the freshwater protist diversity. PLoS One 8:e58950. doi: 10.1371/journal.pone.0058950

44. Legendre P, Legrendre L (1998) Numerical ecology. Developments in environmental modelling. Elsevier Science \& Technology 
45. Dray S, Legendre P, Blanchet FG (2013) packfor: Forward Selection with permutation (Canoco p.46). R Packag. version 0.0-8/r109

46. Escofier B, Pagès J (1994) Multiple factor analysis (AFMULT package). Comput Stat Data Anal 18:121-140. doi: http://dx.doi.org/10.1016/0167-9473(94)90135-X

47. Husson F, Josse J, Le S, Mazet J (2013) FactoMineR: multivariate exploratory data analysis and data mining with $\mathrm{R}$.

48. Dray S, Dufour A-B (2007) The ade4 package: implementing the duality diagram for ecologists. J Stat Softw 22:1-20.

49. Spang A, Saw JH, Jørgensen SL, et al (2015) Complex archaea that bridge the gap between prokaryotes and eukaryotes. Nature. doi: 10.1038/nature14447

50. Kubo K, Lloyd KG, F Biddle J, et al (2012) Archaea of the Miscellaneous Crenarchaeotal Group are abundant, diverse and widespread in marine sediments. ISME J 6:1949-1965. doi: 10.1038/ismej.2012.37

51. Lozupone CA, Knight R (2007) Global patterns in bacterial diversity. Proc Natl Acad Sci 104:11436-11440. doi: 10.1073/pnas.0611525104

52. Zinger L, Amaraf-Zettler LA, Fuhrman JA, et al (2011) Global patterns of bacterial beta-diversity in seafloor and seawater ecosystems. PLoS One 6:e24570. doi: 10.1371 /journal.pone.0024570

53. Kopf A, Bicak M, Kottmann R, et al (2015) The ocean sampling day consortium. Gigascience 4:1-5. doi: 10.1186/s13742-015-0066-5

54. Pesant S, Not F, Picheral M, et al (2015) Open science resources for the discovery and analysis of Tara Oceans data. Sci Data. doi: 10.1038/sdata.2015.23

55. Poulin M, Massé G, Belt ST, et al (2004) Morphological, biochemical and molecular evidence for the transfer of Gyrosigma nipkowii Meister to the genus Haslea (Bacillariophyta). Eur J Phycol 39:181-195. doi: 10.1080/0967026042000202136 
56. Blazewicz SJ, Barnard RL, Daly RA, Firestone MK (2013) Evaluating rRNA as an indicator of microbial activity in environmental communities: limitations and uses. ISME J 7:2061-2068. doi: 10.1038/ismej.2013.102

57. Hugoni M, Agogué H, Taib N, et al (2015) Temporal Dynamics of Active Prokaryotic Nitrifiers and Archaeal Communities from River to Sea. Microb Ecol 70:473-83. doi: $10.1007 / \mathrm{s} 00248-015-0601-\mathrm{z}$

58. Campbell LI, Rota-Stabelli O, Edgecombe GD, et al (2011) MicroRNAs and phylogenomics resolve the relationships of Tardigrada and suggest that velvet worms are the sister group of Arthropoda. Proc Natl Acad Sci U S A 108:15920-4. doi: 10.1073/pnas. 1105499108

59. Lavergne C, Agogué H, Leynaert A, et al (2017) Factors influencing prokaryotes in an intertidal mudflat and the resulting depth gradients, Estuar Coast Shelf Sci 189C:7483. doi: $10.1016 /$ j.ecss. 2017.03 .008

60. Brock J, Schulz-Vogt HN (2011) Sulfide induces phosphate release from polyphosphate in cultures of a marine Beggiatoa strain. ISME J 5:497-506. doi: 10.1038/ismej.2010.135

61. Sun MY, Dafforn KA, Johnston EL, Brown M V (2013) Core sediment bacteria drive community response to anthropogenic contamination over multiple environmental gradients. Environ Microbiol 15:2517-2531. doi: 10.1111/1462-2920.12133

62. Bowman JP, McCuaig RD (2003) Biodiversity, community structural shifts, and biogeography of prokaryotes within Antarctic continental shelf Sediment. Appl Environ Microbiol 69:2463-2483. doi: 10.1128/aem.69.5.2463-2483.2003

63. Ravenschlag K, Sahm K, Knoblauch C, et al (2000) Community Structure, Cellular rRNA Content, and Activity of Sulfate-Reducing Bacteria in Marine Arctic Sediments. Appl Environ Microbiol 66:3592-3602. doi: 10.1128/aem.66.8.3592-3602.2000 
64. Pfeffer C, Larsen S, Song J, et al (2012) Filamentous bacteria transport electrons over $\begin{array}{llll}\text { centimetre } & \text { distances. } & \text { Nature }\end{array}$ http://www.nature.com/nature/journal/v491/n7423/abs/nature1 1586.html\#supplementar y-information

65. Lee YK, Hong SG, Cho HH, et al (2007) Dasania marina gen. nov., sp. nov., of the order Pseudomonadales, isolated from Arctic marine sediment. J Microbiol 45:505.

66. Fuerst JA, Sagulenko E (2011) Beyond the bacterium: Planctomycetes challenge our concepts of microbial structure and function. Nat Rev Micro 9:403-413.

67. Schlesner H (1994) The Development of Media Suitable for the Microorganisms Morphologically Resembling Planctomyces spp., Pirellula spp., and other Planctomycetales from Various Aquatic Habitats Using Dilute Media. Syst Appl Microbiol 17:135-145. doi: 10.1016/S0723-2020(11)80042-1

68. Papineau D, Walker JJ, Mojzsis SJ, Pace NR (2005) Composition and structure of microbial communities from stromatolites of Hamelin Pool in Shark Bay, Western Australia. Appl Environ Microbiol 71:4822-4832. doi: 10.1128/AEM.71.8.48224832.2005

69. Kulichevskaya IS, Ivanoya AO, Baulina OI, et al (2008) Singulisphaera acidiphila gen. nov., sp. nov., a non-filamentous, Isosphaera-like planctomycete from acidic northen wetlands. Int J Syst Evol Microbiol 58:1186-1193. doi: 10.1099/ijs.0.65593-0

70. Giovannoni SJ, Schabtach E, Castenholz RW (1987) Isosphaera pallida, gen. and comb. nov., a gliding, budding eubacterium from hot springs. Arch Microbiol 147:276284. doi: 10.1007/BF00463488

71. Strous M, Fuerst JA, Kramer EHM, et al (1999) Missing lithotroph identified as new planctomycete. Nature 400:446-449.

72. Devol AH (2003) Nitrogen cycle: Solution to a marine mystery. Nature 422:575-576. 
73. Kuenen JG (2008) Anammox bacteria: from discovery to application. Nat Rev Micro $6: 320-326$.

74. Kartal B, Kuypers MMM, Lavik G, et al (2007) Anammox bacteria disguised as denitrifiers: nitrate reduction to dinitrogen gas via nitrite and ammonium. Environ Microbiol 9:635-642. doi: 10.1111/j.1462-2920.2006.01183.x

75. Jetten MSM, van Niftrik L, Strous M, et al (2009) Biochemistry and molecular biology of anammox bacteria. Crit Rev Biochem Mol Biol 44:65-84. doi: doi:10.1080/10409230902722783

76. Agogué H, Brink M, Dinasquet J, Herndl GJ (2008) Major gradients in putatively nitrifying and non-nitrifying Archaea in the deep North Atlantic, Nature 456:788-791. doi: $10.1038 /$ nature 07535

77. Santoro AE, Casciotti KL, Francis CA (2010) Activity, abundance and diversity of nitrifying archaea and bacteria in the central California Current. Environ Microbiol 12:1989-2006. doi: 10.1111/j.1462-2920.2010.02205.x

78. Villanueva L, Schouten S, Sinninghe Damsté JS (2015) Depth-related distribution of a key gene of the tetraether lipid biosynthetic pathway in marine Thaumarchaeota. Environ Microbiol 17:3527-3539. doi: 10.1111/1462-2920.12508

79. Smith JM, Casciotti KL, Chavez FP, Francis CA (2014) Differential contributions of archaeal ammonia oxidizer ecotypes to nitrification in coastal surface waters. ISME J 8:1704-1714. doi: 10.1038/ismej.2014.11

80. Damashek J, Smith JM, Mosier AC, Francis CA (2015) Benthic ammonia oxidizers differ in community structure and biogeochemical potential across a riverine delta. Front Microbiol 5:743. doi: 10.3389/fmicb.2014.00743

81. Francis CA, Robert KJ, Beman JM, et al (2005) Ubiquity and diversity of ammoniaoxidizing archaea in water columns and sediments of the ocean. Proc Natl Acad Sci 
102:14683-14688.

82. Smith JM, Mosier A, Francis CA (2014) Spatiotemporal relationships between the abundance, distribution, and potential activities of ammonia-oxidizing and denitrifying microorganisms in intertidal sediments. Microb Ecol 1-12. doi: 10.1007/s00248-014$0450-1$

83. Auguet J-C, Casamayor EO (2013) Partitioning of Thaumarchaeota populations along environmental gradients in high mountain lakes. FEMS Microbiol Ecol 84:154-164. doi: $10.1111 / 1574-6941.12047$

84. Hugoni M, Domaizon I, Taib N, et al (2015) Temporal dynamics of active Archaea in oxygen-depleted zones of two deep lakes. Environ Microbiol Rep 7:321-9. doi: $10.1111 / 1758-2229.12251$

85. Jung M-Y, Park S-J, Kim S-J, et al (2014) A mesophilic, autotrophic, ammoniaoxidizing archaeon of Thaumarchaeal group I.1a cultivated from a deep oligotrophic soil horizon. Appl Environ Microbiol 80:3645-3655. doi: 10.1128/aem.03730-13

86. Prosser JI, Nicol GW, Venter JC, et al (2012) Archaeal and bacterial ammoniaoxidisers in soil: the quest for niche specialisation and differentiation. Trends Microbiol 20:523-531. doi: 10.1016/j.tim.2012.08.001

87. Dang H, Zhou H, Yang J, et al (2013) Thaumarchaeotal signature gene distribution in sediments of the northern South China sea: An indicator of the metabolic intersection of the marine carbon, nitrogen, and phosphorus cycles? Appl Environ Microbiol 79:2137-2147. doi: 10.1128/AEM.03204-12

88. Bale NJ, Villanueva L, Hopmans EC, et al (2013) Different seasonality of pelagic and benthic Thaumarchaeota in the North Sea. Biogeosciences 10:7195-7206. doi: $10.5194 /$ bg-10-7195-2013

89. Stauffert M, Duran R, Gassie C, Cravo-Laureau C (2014) Response of archaeal 
communities to oil spill in bioturbated mudflat sediments. Microb Ecol 67:108-119. doi: 10.1007/s00248-013-0288-y

90. Meng J, Xu J, Qin D, et al (2014) Genetic and functional properties of uncultivated MCG archaea assessed by metagenome and gene expression analyses. ISME J 8:650659. doi: $10.1038 /$ ismej.2013.174

91. Hawkins AN, Johnson KW, Bräuer SL (2014) Southern appalachian peatlands support high archaeal diversity. Microb Ecol 67:587-602. doi: 10.1007/s00248-013-0352-7

92. Hirayama H, Sunamura M, Takai K, et al (2007) Culture-dependent and -independent characterization of microbial communities associated with a shallow submarine hydrothermal system occurring within a coral reef off Taketomi Island, Japan. Appl Environ Microbiol 73:7642-7656. doi: 10.1128/aem.01258-07

93. Wemheuer B, Taube R, Akyol P, et al (2013) Microbial diversity and biochemical potential encoded by thermal spring metagenomes derived from the Kamchatka peninsula. Archaea 2013:13. doi: 10.1155/2013/136714

94. Fang J, Shizuka A, Kato C, Schouten S (2006) Microbial diversity of cold-seep sediments in Sagami Bay, Japan, as determined by 16S rRNA gene and lipid analyses. FEMS Microbiol Ecol 57:429-441. doi: 10.1111/j.1574-6941.2006.00126.x

95. Dang H, Luan X-W, Chen R, et al (2010) Diversity, abundance and distribution of amoA-encoding archaea in deep-sea methane seep sediments of the Okhotsk Sea. FEMS Microbiol Ecol 72:370-385. doi: 10.1111/j.1574-6941.2010.00870.x

96. Oksanen J, Blanchet FG, Kindt R, et al (2013) vegan: Community Ecology Package. R Packag. version 2.0-7 


\section{Figure legends}

2 Figure 5. Schematic view of the experimental design. a) One mesocosm consisted of two

3 tanks: a main and overflow tank; b) schedule for the Day and Night mesocosms.

4 Figure 6. Individual map from the multiple factor analysis (MFA) and inertia due to

5 each factor. a) Each sample name represents the barycentre of the two positions according to

6 the dataset: Bacteria (green) and Archaea (purple). The samples from Day experiment are

7 circles and Night experiment samples are squares). Sediment depths $(\mathrm{D} 1=0-0.5 \mathrm{~cm} ; \mathrm{D} 2=0.5-1$

$8 \mathrm{~cm} ; \mathrm{D} 3=1-2 \mathrm{~cm} ; \mathrm{D} 4=2-5 \mathrm{~cm} ; \mathrm{D} 5=5-10 \mathrm{~cm}$ ) are highlighted using ordihull from the 'vegan'

9 package [96]. Pie charts ( $b$ and $c$ ) show the inertia of the MFA due to each factor: b)

10 Sediment depth and c) Day/Night experiment.

11 Figure 7. Distribution of bacterial 16S rRNA transcripts, The relative abundance of the

12 16S rRNA transcripts and the affiliation of the total bacterial operational taxonomic units

13 (OTUs 97\%) at the phylum level (except for Proteobacteria, class level) between the two Day

14 and Night treatments among the five layers below the sediment surface (bsf). Environmental

15 group contained BHI80-139, Candidate division OD1, Candidate division OP3, Candidate

16 division TM7, Candidate division WS3, EM19, GOUTA4, Hyd24-12, JL-ETNP-Z39, LD1-

17 PA38, NPL-UPA2, TA06 and TM6. Note that plastids originated from microalgae were

18 removed from the dataset.

19 Figure 8. Distribution of archaeal 16S rRNA transcripts. The relative abundance of the

20 16S rRNA transcripts and the affiliation of the total archaeal operational taxonomic units

21 (OTUs 97\%) at the class level between the two Day and Night treatments among the five

22 layers below the sediment surface (bsf). 


\section{Acknowledgments}

24 This research was supported by a PhD grant from the Charente Maritime Department and by 25 the national program CPER 2006-2013 (Contrat Projet Etat Région) of Charente Maritime, 26 the French national program EC2CO (CAPABIOC, 2012-2014), and the CNRS organism. 27 The tidal mesocosms were built by M. Prineau and N. Lachaussée. We acknowledge the 28 Molecular and the Cytometry Core Facilities at LIENSs laboratory. Authors are grateful to A. 29 Leynaert (LEMAR, Brest, France) for the rhizons technique, to P. Pineau (LIENSs, La

30 Rochelle, France) for the nutrient measurement and to N. Lachaussee (LIENSs, La Rochelle, 31 France) for field sampling. We also thank V. Becquet, C. Dussud, M. Bréret, J.C. Gama de 32 Matos and J. Lavaud (LIENSs, La Rochelle, France) who help us during the experiment. We 33 thank N. Taib and JC. Charvy (LMGE, Clermont-Ferrand, France) for their help in 34 phylogenetic analyses. 